\title{
A genome-wide screen identifies genes required for formation of the wobble nucleoside 5-methoxycarbonylmethyl-2-thiouridine in Saccharomyces cerevisiae
}

\author{
BO HUANG, ${ }^{\mathbf{1}}$ JIAN LU, ${ }^{\mathbf{1 , 2}}$ and ANDERS S. BYSTRÖM \\ Department of Molecular Biology, Umeå University, 90187 Umeå, Sweden
}

\begin{abstract}
We recently showed that the $\gamma$-subunit of Kluyveromyces lactis killer toxin ( $\gamma$-toxin) is a tRNA endonuclease that cleaves

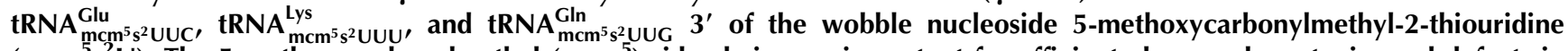
$\left(\mathrm{mcm}^{5} \mathrm{~s}^{2} \mathrm{U}\right)$. The 5-methoxycarbonylmethyl $\left(\mathrm{mcm}^{5}\right)$ side chain was important for efficient cleavage by $\gamma$-toxin, and defects in $\mathbf{m c m}^{5}$ side-chain synthesis correlated with resistance to $\gamma$-toxin. Based on this correlation, a genome-wide screen was performed to identify gene products involved in the formation of the $\mathrm{mcm}^{5}$ side chain. From a collection of 4826 homozygous diploid Saccharomyces cerevisiae strains, each with one nonessential gene deleted, 63 mutants resistant to Kluyveromyces lactis killer toxin were identified. Among these, eight were earlier identified to have a defect in formation of the $\mathrm{mcm}^{5}$ side $\mathrm{chain}$ Analysis of the remaining mutants and other known $\gamma$-toxin resistant mutants revealed that sit4, kti14, and KTI5 mutants also have a defect in the formation of $\mathrm{mcm}^{5}$. A mutant lacking two of the Sit4-associated proteins, Sap185 and Sap190, displays the same modification defect as a sit4-null mutant. Interestingly, several mutants were found to be defective in the synthesis of the 2-thio $\left(\mathrm{s}^{2}\right)$ group of the $\mathrm{mcm}^{5} \mathrm{~s}^{2} U$ nucleoside. In addition to earlier described mutants, formation of the $\mathrm{s}^{2}$ group was also abolished in urm1, uba4, and ncs 2 mutants and decreased in the yor $251 \mathrm{c}$ mutant. Like the absence of the $\mathrm{mcm}^{5}$ side chain, the lack of the $s^{2}$ group renders $t R N A_{\mathrm{mcm}^{5} s^{2} U U C}^{G l u}$ less sensitive to $\gamma$-toxin, reinforcing the importance of the wobble nucleoside $\mathrm{mcm}^{5} \mathrm{~s}^{2} U$ for $\mathrm{tRNA}$ cleavage by $\gamma$-toxin.
\end{abstract}

Keywords: K. lactis $\gamma$-toxin; 5-methoxycarbonylmethyl-2-thiouridine; SIT4; SAP185; SAP190; KTI14; KTI5; URM1; UBA4; NCS2; YOR251C

\section{INTRODUCTION}

Kluyveromyces lactis killer toxin (zymocin) is secreted by killer strains of $K$. lactis and inhibits growth of sensitive yeast strains, such as Saccharomyces cerevisiae (Stark et al. 1990; Schaffrath and Meinhardt 2005; Jablonowski and Schaffrath 2007). Zymocin consists of three subunits- $\alpha, \beta$, and $\gamma$-that are encoded from a linear plasmid. Cytotoxicity of zymocin resides in the $\gamma$ subunit, since intracellular

\footnotetext{
${ }^{1}$ These authors contributed equally to this work.

${ }^{2}$ Present address: Laboratory of Molecular Gerontology, National Institute on Aging, 5600 Nathan Shock Drive, Baltimore, MD 212246825, USA.

Reprint requests to: Anders S. Byström, Department of Molecular Biology, Umeå University, 90187 Umeå, Sweden; e-mail: anders.bystrom@ molbiol.umu.se; fax: 46-90-77-26-30.

Article published online ahead of print. Article and publication date are at http://www.rnajournal.org/cgi/doi/10.1261/rna.1184108.
}

expression of this subunit in $S$. cerevisiae mimics the action of zymocin (Butler et al. 1991a). The $\alpha$ and $\beta$ subunits are required for the secretion of zymocin and docking of zymocin to other cells. In addition, the $\beta$ subunit is possibly involved in the translocation of the $\gamma$ subunit into the sensitive cells (Stark et al. 1990; Schaffrath and Meinhardt 2005).

Numerous $S$. cerevisiae mutants resistant to zymocin have been isolated (Kawamoto et al. 1993; Butler et al. 1994; Kishida et al. 1996; Frohloff et al. 2001). The zymocin-resistant mutants can be divided into two classes. Class I mutants are resistant to exterior zymocin but sensitive to intracellular expression of $\gamma$-toxin. Hence, they are defective in the docking/uptake of zymocin. Class II mutants are resistant both to exterior zymocin and endogenously expressed $\gamma$-toxin, and thus are proposed to be target mutants. So far, 14 class II mutants have been 
identified, namely, elp1, elp2, elp3 (Frohloff et al. 2001), elp4, elp5, elp6 (Jablonowski et al. 2001b), kti11, kti12, kti13 (Butler et al. 1994; Fichtner and Schaffrath 2002; Fichtner et al. 2002a), trm9 (Lu et al. 2005; Jablonowski et al. 2006), kti14 (Mehlgarten and Schaffrath 2003), sit4, a sap185 sap190 double mutant (Jablonowski et al. 2001a, 2004), and urm1 (Fichtner et al. 2003).

Ten of the class II zymocin-resistant mutants have been shown to be defective in the formation of modified uridine residues at the wobble position in tRNA. The Elplp-Elp6p, Kti11p-Kti13p are all required for an early step in the formation of 5-methoxycarbonylmethyl $\left(\mathrm{mcm}^{5}\right)$ and 5carbamoylmethyl $\left(\mathrm{ncm}^{5}\right)$ side chains on wobble uridines in 11 tRNA species (Huang et al. 2005; Lu et al. 2005; Johansson et al. 2008), whereas the Trm9p is required for the last step of $\mathrm{mcm}^{5}$ synthesis (Kalhor and Clarke 2003). Consistent with the correlation between class II zymocin resistance and tRNA wobble uridine modification deficiency (Huang et al. 2005), we showed that $\gamma$-toxin is an endonuclease that cleaves tRNAs containing the wobble nucleoside 5-methoxycarbonylmethyl-2-thiouridine $\left(\mathrm{mcm}^{5} \mathrm{~s}^{2} \mathrm{U}\right)$ (Lu et al. 2005). In $S$. cerevisiae, the $\mathrm{mcm}^{5} \mathrm{~s}^{2} \mathrm{U}$ nucleoside is present in $\mathrm{tRNA}_{\mathrm{mcm}^{5} \mathrm{~s}^{2} \mathrm{UUC}}^{\mathrm{Glu}}$, $\mathrm{RNA}_{\mathrm{mcm}^{5} \mathrm{~s}^{2} \mathrm{UUS}}^{\mathrm{Lys}}$, and $\mathrm{tRNA}_{\mathrm{mcm} \mathrm{s}^{2} \mathrm{UUG}}^{\mathrm{Gln}}$. The $\mathrm{mcm}^{5}$ side chain on the wobble uridine in tRNAs is required for efficient cleavage, explaining why the modification-deficient mutants elp1-elp6, kti11-kti13, and trm 9 are resistant to $\gamma$-toxin. In addition to the strong stimulatory effect of the $\mathrm{mcm}^{5}$ side chain, we recently showed that the $s^{2}$ group of $m \mathrm{~mm}^{5} \mathrm{~s}^{2} \mathrm{U}$ has a weak positive effect on in vitro cleavage of tRNA substrates by $\gamma$-toxin ( $\mathrm{Lu}$ et al. 2008).

Since class II zymocin resistance correlates with $\mathrm{mcm}^{5}$ modification deficiency ( $\mathrm{Lu}$ et al. 2005), it seemed possible that a screen for zymocin resistance would enable the isolation of mutants affecting the formation of the $\mathrm{mcm}^{5}$ side chain. Here we describe such a screen using a collection of $S$. cerevisiae homozygous diploid deletion strains, each of which has one nonessential gene deleted. This systematic screen identified not only proteins required for the formation of $\mathrm{mcm}^{5}$ side chain, but also proteins involved in the synthesis of the $s^{2}$ group.

\section{RESULTS}

\section{Identification of mutants resistant to zymocin and defective in wobble uridine modification}

Zymocin resistance of 4826 homozygous diploid deletion strains of $S$. cerevisiae was examined by using the eclipse assay (Kishida et al. 1996). The S. cerevisiae deletion strains to be tested were spotted on rich plates, and the zymocinproducing $K$. lactis strain was inoculated on the edge of the spot. The size of the clearing zone caused by zymocin was compared between the mutants and the sensitive wildtype strain. Decreased size of clearing zone was scored for
63 mutants, showing that they are resistant to zymocin. According to the size of the clearing zone, the zymocinresistant mutants were further divided into fully resistant and partially resistant groups (Fig. 1A; Tables 1, 2). As expected, the elp1-elp4, elp6, kti12, kti13 (Huang et al. 2005), and trm9 (Kalhor and Clarke 2003) mutants, which are all defective in the formation of the wobble $\mathrm{mcm}^{5}$ group in target tRNAs, were found among the fully resistant strains. To investigate if any of the other mutants had a defect in wobble uridine modifications, total tRNA prepared from the wild-type strain and zymocin-resistant mutants were analyzed by HPLC (Fig. 2; Tables 1, 2). In addition to those aforementioned mutants, a sit4 mutant was found to be deficient in the formation of $\mathrm{mcm}^{5}$ and $\mathrm{ncm}^{5}$ side chains (Tables 1, 3). Interestingly, in addition to the earlier described $n f s 1, c f d 1, n b p 35$, cial, an isu1 isu2 double mutant and the ncs6/tuc1 mutant (Nakai et al. 2004, 2007; Björk et al. 2007), we also found that urm1, uba4, ncs2, and yor251c mutants are affected in the formation of the $s^{2}$ group in tRNA.

\section{A sit4-null mutant is deficient in the formation of $\mathrm{mcm}^{5}$ and $\mathrm{ncm}^{5}$ side chains in tRNA}

The Sit4 protein is a protein phosphatase that plays a critical role in cell growth and proliferation (Sutton et al. 1991). Consistent with its class II zymocin resistance (Jablonowski et al. 2001a), a sit4-null mutant is deficient in the formation of $\mathrm{mcm}^{5}$ and $\mathrm{ncm}^{5}$ side chains. By analyzing total tRNA or

A
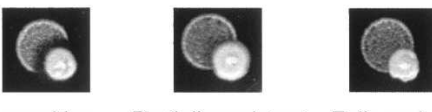

sensitive Partially resistant Fully resistant

B

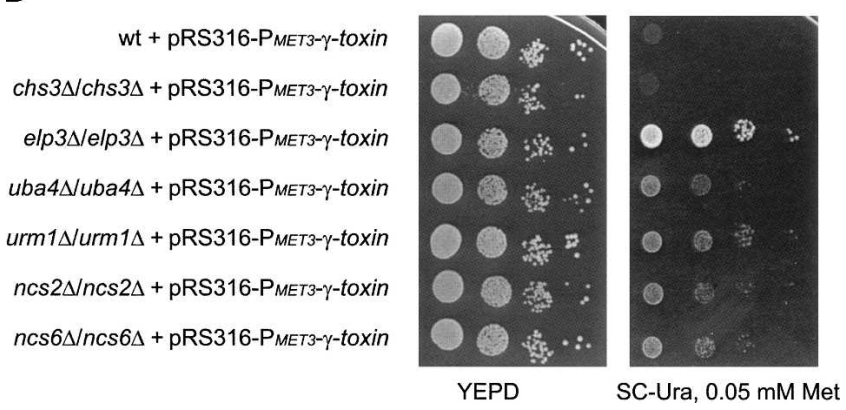

FIGURE 1. Identification of mutants resistant to zymocin. (A) The $S$. cerevisiae deletion strains to be tested were spotted on YEPD plates, and the zymocin-producing $K$. lactis strain 2105-1D (Gunge and Sakaguchi 1981) was inoculated on the edge of the spot. After $24 \mathrm{~h}$ of incubation at $30^{\circ} \mathrm{C}$, the size of the clearing zone caused by zymocin was compared between the mutants and the sensitive wild-type strain. $(B)$ The indicated strains were transformed with a plasmid containing a $\mathrm{P}_{M E T 3}$-driven $\gamma$-toxin gene (pABY1728). Transformants were 10fold serially diluted and grown on YEPD or synthetic complete plates lacking uracil and containing $0.05 \mathrm{mM}$ methionine for $2 \mathrm{~d}$ at $30^{\circ} \mathrm{C}$. All strains were from the $S$. cerevisiae deletion collection, except the urm $1 \Delta /$ urm $1 \Delta$ strain (UMY3553). 
TABLE 1. Content of modified nucleosides in tRNA isolated from wild type and mutants fully resistant to zymocin

\begin{tabular}{|c|c|c|c|}
\hline Strain $^{\mathrm{a}}$ & $\mathrm{mcm}^{5} \mathrm{U} / \psi$ & $\mathrm{mcm}^{5} \mathrm{~s}^{2} \mathrm{U} / \psi$ & $s^{2} U / \psi$ \\
\hline$W t$ & 1.00 & 1.00 & - \\
\hline elp1 & $<0.04^{\mathrm{b}}$ & $<0.04^{\text {b }}$ & + \\
\hline elp2 & $<0.04$ & $<0.04$ & + \\
\hline elp3 & $<\mathbf{0 . 0 8}$ & $<\mathbf{0 . 0 8}$ & + \\
\hline elp4 & $<\mathbf{0 . 0 8}$ & $<\mathbf{0 . 0 8}$ & + \\
\hline elp6 & $<0.05$ & $<0.05$ & + \\
\hline kti12 & $<0.08$ & $<\mathbf{0 . 0 8}$ & + \\
\hline kti13 & 0.48 & 0.64 & + \\
\hline sit4 & $<0.05$ & $<0.05$ & + \\
\hline trm9 & $<0.05$ & $<0.05$ & - \\
\hline cka2 & 1.10 & 0.93 & - \\
\hline chs3 & 0.90 & 1.00 & - \\
\hline chs7 & 0.99 & 0.95 & - \\
\hline$r p / 20 b$ & 0.95 & 0.86 & - \\
\hline$r p / 22 a$ & 1.01 & 0.80 & - \\
\hline loc1 & 0.86 & 0.77 & - \\
\hline rai1 & 0.79 & 0.79 & - \\
\hline ipt1 & 0.76 & 0.82 & - \\
\hline yvh1 & 1.07 & 0.98 & - \\
\hline slm6 & 1.04 & 0.94 & - \\
\hline kap120 & 0.92 & 1.27 & - \\
\hline$m t q 2$ & 1.05 & 0.90 & - \\
\hline uba4 & 2.02 & $<0.07$ & - \\
\hline$n c s 2$ & 2.50 & $<0.05$ & - \\
\hline ncs6 & 2.51 & $<0.05$ & - \\
\hline urm1* & 3.05 & $<0.06$ & - \\
\hline kti14* & $<0.07$ & $<0.07$ & + \\
\hline KTI5* & $<0.04$ & $<0.04$ & + \\
\hline$K T I 5 / W t^{*}$ & $<0.04$ & $<0.04$ & + \\
\hline
\end{tabular}

$(\psi)$ Pseudouridine; $\left(\mathrm{s}^{2} \mathrm{U}\right)$ 2-thiouridine; $\left(\mathrm{mcm}^{5} \mathrm{U}\right) 5$-methoxycarbonylmethyl-uridine; $\left(\mathrm{mcm}^{5} \mathrm{~s}^{2} \mathrm{U}\right)$ 5-methoxycarbonylmethyl-2-thiouridine; "-" indicates no detection of $\mathrm{s}^{2} \mathrm{U}$; and " + " indicates presence of $s^{2} U$. Pseudouridine $(\psi)$ was used as the internal standard. The numbers given are the ratios of the various modified nucleosides (modified nucleoside/ $\psi$ ) in bulk tRNA isolated from the indicated mutant normalized to the ratio in the wild-type strain. Mutants affected in modification are shown in bold. *Strains UMY3276 (KTI5) and UMY3464 (KTI5/wt) were constructed in a W303 background, and strains UMY3430 (urm1 $1 \Delta$ ) and UMY3408 ( $k$ ti14A) were constructed in a W303 background containing the SSD1-v1 allele.

${ }^{a}$ Except strains marked with an asterisk $(*)$, the strains are from the yeast homozygous diploid deletion collection (Research Genetics).

${ }^{\mathrm{b}}$ Detection limit.

purified tRNA species from the sit4-null mutant, we found that the $\mathrm{mcm}^{5}$ and $\mathrm{mcm}^{5} \mathrm{~s}^{2} \mathrm{U}$ nucleosides were absent in total tRNA, and $\mathrm{mcm}^{5} \mathrm{U}, \mathrm{ncm}^{5} \mathrm{U}$, and $\mathrm{mcm}^{5} \mathrm{~s}^{2} \mathrm{U}$ nucleosides were absent in purified tRNA $\mathrm{mcm}^{5} \mathrm{UCU}, \mathrm{tRNA}_{\mathrm{ncm}^{5} \mathrm{UGG}}^{\mathrm{Aro}}$, and $\mathrm{tRNA}_{\mathrm{mcm}^{5} \mathrm{~s}^{2} \mathrm{UUC}}^{\mathrm{Glu}}$, respectively (Tables 1,3 ). No intermediates of $\mathrm{mcm}^{5} \mathrm{U}$ and $n \mathrm{~cm}^{5} \mathrm{U}$ were observed in tRNA ${ }^{\mathrm{Arg}}$ and tRNA ${ }^{\text {Pro }}$ prepared from the sit4-null mutant, suggesting that the defect of the sit4 mutant is in an early step of $\mathrm{mcm}{ }^{5} \mathrm{U}$ and $\mathrm{ncm}^{5} \mathrm{U}$ biosynthesis. In both total tRNA and purified tRNA $\mathrm{s}^{2} \mathrm{GUC}$ from a sit4-null mutant, 2-thiouridine $\left(\mathrm{s}^{2} \mathrm{U}\right)$ was observed, demonstrating that thiolation at position 2 is not affected (Tables 1, 3).

\section{Mutants defective in the formation of 2-thio group of $\mathrm{mcm}^{5} \mathrm{~s}^{2} \mathrm{U}$ are resistant to zymocin}

In addition to the mcm group at position 5 of wobble uridines, $\gamma$-toxin substrate tRNAs, i.e., tRNA $\mathrm{mcm}^{5} \mathrm{~s}^{2} \mathrm{UUC}$, $\mathrm{tRNA}_{\mathrm{mcm}^{5} \mathrm{~s}^{2} \mathrm{UUU}}^{\mathrm{Lys}}$, and $\mathrm{tRNA} \mathrm{mcm}_{\mathrm{mc}}^{\mathrm{Gln} \mathrm{s}^{2} \mathrm{UUG}}$ contain an $\mathrm{s}^{2}$ group on the wobble uridine. Interestingly, besides mutants deficient in the $\mathrm{mcm}^{5}$ formation, the present screen also identified

TABLE 2. Content of modified nucleosides in tRNA isolated from wild type and mutants partially resistant to zymocin

\begin{tabular}{|c|c|c|c|}
\hline Strain $^{a}$ & $\mathrm{mcm}^{5} \mathrm{U} / \psi$ & $\mathrm{mcm}^{5} \mathrm{~s}^{2} \mathrm{U} / \psi$ & $\mathrm{s}^{2} \mathrm{U} / \psi$ \\
\hline$W t$ & 1.00 & 1.0 & - \\
\hline hmo1 & 0.93 & 0.79 & - \\
\hline bud28 & 1.13 & 1.17 & - \\
\hline$r p / 8 b$ & 1.35 & 1.03 & - \\
\hline sky1 & 1.10 & 0.77 & - \\
\hline ymr193c-a & 1.12 & 1.04 & - \\
\hline rrp6 & 1.10 & 1.03 & - \\
\hline rpa49 & 1.00 & 0.85 & - \\
\hline$r p s 9 b$ & 0.76 & 0.86 & - \\
\hline bud21 & 1.14 & 0.99 & - \\
\hline uaf3o & 1.09 & 1.04 & - \\
\hline nop12 & 0.95 & 1.15 & - \\
\hline $\mathrm{rm} / 2$ & 0.83 & 0.94 & - \\
\hline $\operatorname{arx} 1$ & 1.04 & 0.88 & - \\
\hline rei1 & 1.01 & 1.26 & - \\
\hline ado1 & 0.78 & 0.86 & - \\
\hline cup5 & 0.81 & 1.14 & - \\
\hline vmas & 0.92 & 1.46 & - \\
\hline ygr160w & 1.08 & 1.23 & - \\
\hline ssf1 & 0.86 & 0.92 & - \\
\hline wma22 & 0.84 & 0.96 & - \\
\hline yor251c & 1.92 & 0.29 & - \\
\hline bud19 & 0.87 & 0.93 & - \\
\hline ski8 & 1.17 & 0.82 & - \\
\hline tcl1 & 1.06 & 1.31 & - \\
\hline skt5 & 1.37 & 0.78 & - \\
\hline$r p / 19 b$ & 1.03 & 1.14 & - \\
\hline rpl24a & 1.05 & 1.05 & - \\
\hline$d b p 3$ & 0.88 & 1.24 & - \\
\hline ies2 & 0.99 & 1.21 & - \\
\hline$d b p 7$ & 1.29 & 0.98 & - \\
\hline cst6 & 1.43 & 0.88 & - \\
\hline hit1 & 1.07 & 1.09 & - \\
\hline rpl7a & 1.00 & 1.16 & - \\
\hline prm5 & 1.09 & 0.78 & - \\
\hline rp/39 & 1.02 & 1.00 & - \\
\hline trk1 & 1.25 & 0.91 & - \\
\hline$y d l 062 w$ & 1.23 & 0.86 & - \\
\hline Sur4 & 0.90 & 0.91 & - \\
\hline
\end{tabular}

$(\psi)$ Pseudouridine; $\left(\mathrm{s}^{2} \mathrm{U}\right)$ 2-thiouridine; $\left(\mathrm{mcm}^{5} \mathrm{U}\right) 5$-methoxycarbonylmethyl-uridine; $\left(\mathrm{mcm}^{5} \mathrm{~s}^{2} \mathrm{U}\right)$ 5-methoxycarbonylmethyl-2-thiouridine; and "-" indicates no detection of $s^{2} U$. Pseudouridine $(\psi)$ was used as the internal standard. The numbers given are the ratios of the various modified nucleosides (modified nucleoside $/ \psi$ ) in bulk tRNA isolated from the indicated mutant normalized to the ratio in the wild-type strain. Mutants affected in modification are shown in bold.

${ }^{\text {a}}$ Strains are from the yeast homozygous diploid deletion collection (Research Genetics). 
A

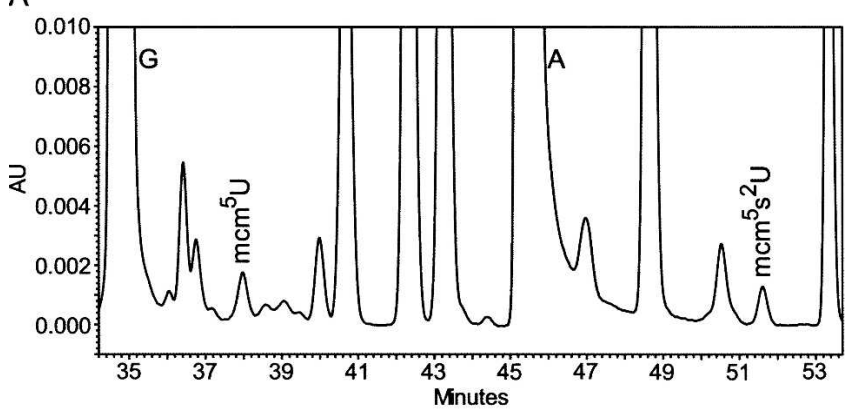

B

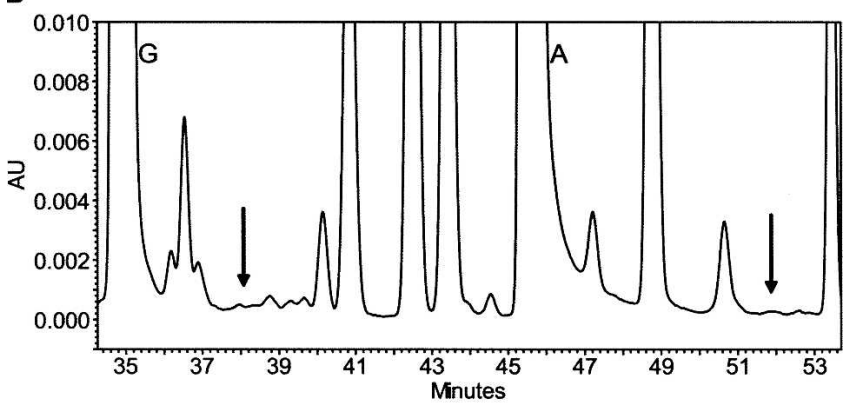

C

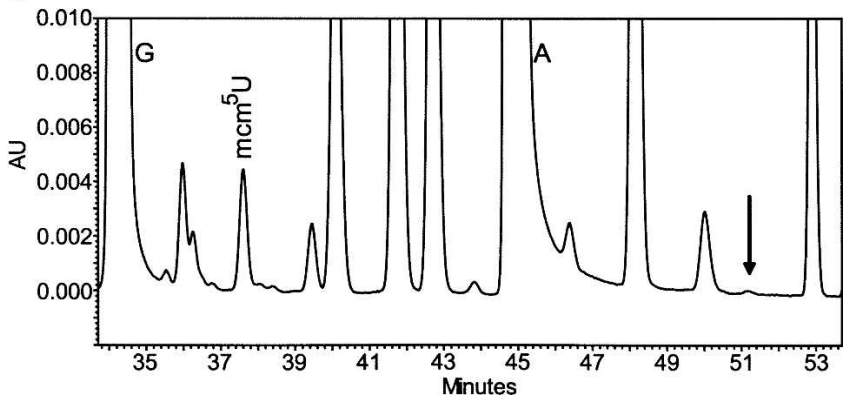

FIGURE 2. HPLC analysis of tRNA from zymocin-resistant strains. HPLC analysis of modified nucleosides of total tRNA from $(A)$ wild type (BY4743) and its isogenic $(B)$ elp1 and $(C) n c s 2$ strain derivatives. $(A, B)$ The 34.2-53.8-min and $(C)$ the 33.6-53.8-min regions of the HPLC chromatograms monitored at $254 \mathrm{~nm}$ are shown. The arrows indicate expected retention times of $\mathrm{mcm}^{5} \mathrm{U}$ and $\mathrm{mcm}^{5} \mathrm{~s}^{2} \mathrm{U}$, respectively.

five mutants affecting the $s^{2}$ modification, including the already defined ncs6/tucl mutant (Björk et al. 2007). As shown in Table 1 and Figure 2, the nucleoside $\mathrm{mcm}^{5} \mathrm{~s}^{2} \mathrm{U}$ was absent, while the levels of $\mathrm{mcm}^{5} \mathrm{U}$ increased in total tRNA from urm $1, u b a 4, n c s 2$, and ncs6/tuc1 mutants. In addition, a reduced level of $\mathrm{mcm}^{5} \mathrm{~s}^{2} \mathrm{U}$ and an increased level of $\mathrm{mcm}^{5} \mathrm{U}$ were seen in the yor251c mutant (Table 2).

It has been shown that an urm1-null strain is resistant to intracellular expression of $\gamma$-toxin (Fichtner et al. 2003). To test if all mutants lacking the $\mathrm{s}^{2}$ group (urm1, uba4, $n c s 2$, and $n c s 6 / t u c 1$ ) are resistant to $\gamma$-toxin, these mutants were transformed with a $\mathrm{P}_{G A L 1}$-driven $\gamma$-toxin plasmid (pABY1472), and growth on galactose plates was examined. In contrast to the previous study, the urm 1 mutant, as well as other mutants lacking the $\mathrm{s}^{2}$ group, were sensitive to $\gamma$-toxin expressed from the $\mathrm{P}_{G A L 1}$ promoter (data not shown). This discrepancy is likely caused by the different expression levels of $\gamma$-toxin, since this study used a different $\gamma$-toxin expression construct from that of the previous report (Fichtner et al. 2003). In accordance with this assumption, all mutants lacking the $\mathrm{s}^{2}$ group (urm1, uba4, ncs2, and $n c s 6 / t u c 1$ ) did show resistance to low intracellular $\gamma$-toxin expression when transformed with a $\mathrm{P}_{M E T 3}$-driven $\gamma$-toxin plasmid (pABY1728) and grown on plates with $0.05 \mathrm{mM}$ methionine (Fig. 1B). The MET3 promoter, a weaker promoter compared to the GAL1 promoter, is partially turned off in the presence of $0.05 \mathrm{mM}$ methionine (Mao et al. 2002). Notably, mutants lacking the $s^{2}$ group were less resistant than the elp3 mutant (Fig. 1B), which lacks the $\mathrm{mcm}^{5}$ side chain (Huang et al. 2005).

Lack of the $\mathrm{mcm}^{5}$ group renders tRNA less sensitive to $\gamma$ toxin cleavage, explaining the $\gamma$-toxin resistance of mutants deficient in the formation of the $\mathrm{mcm}^{5}$ group ( $\mathrm{Lu}$ et al. 2005). To test if this explanation applies to the mutants identified in the present screen, we analyzed the effect of in vivo zymocin treatment and in vitro $\gamma$-toxin treatment on one of the substrate tRNAs (tRNA Glu ). The level of tRNA $A_{U U C}^{\text {Glu }}$ was assayed by Northern blot after adding crude zymocin to log-phase cultures of strains to be tested. As shown in Figure 3A, the level of tRNA $\mathrm{AUC}_{\mathrm{UUC}}^{\text {Glu }}$ decreased in the wild-type cells after zymocin treatment, but remained unchanged in all mutants fully resistant to zymocin. The in vitro tRNA Glu cleavage was examined by treating total RNA isolated from wild-type and zymocinresistant strains with purified $\gamma$-toxin-GST and assaying the level of tRNA Glu $\mathrm{UUC}$ using Northern blot. According to the level of tRNA Glu Gufter in vitro $\gamma$-toxin treatment, zymocin-resistant mutants can be divided into two groups (Fig. $3 \mathrm{~B})$. The first group consists of mutants defective in the formation of the $\mathrm{mcm}^{5}$ or s $\mathrm{s}^{2}$ group, that is, elp1-elp4, elp6, kit12, kti13, sit4, trm9, urm1, uba4, ncs2, and ncs6/tucl. The tRNA Glu GUC isolated from these mutants showed robust or partial resistance to $\gamma$-toxin cleavage. The second group contains all the remaining mutants including several known barrier mutants (chs3, chs7, and ipt1) that showed a similar extent of in vitro tRNA cleavage to the wild-type strain. Presumably, similar to the known barrier mutants, the remaining mutants in the second group could be defective in either the uptake of $\gamma$-toxin or other events prior to $\gamma$-toxin cleavage of substrate tRNAs.

\section{Other mutants with defects in $\mathrm{mcm}^{5}$ and $\mathbf{n c m}^{5}$ group formation}

The systematic screen using the yeast deletion collection reinforced the correlation between class II zymocin resistance and the defects in wobble uridine modification. We extended our investigation to other previously identified class II zymocin-resistant mutants to investigate if they also had a defect in formation of $\mathrm{mcm}^{5} \mathrm{~s}^{2} \mathrm{U}$. 
Genes for formation of tRNA nucleoside $\mathrm{mcm}^{5} \mathrm{~s}^{2} U_{34}$

\begin{tabular}{|c|c|c|c|c|c|c|c|c|c|}
\hline tRNA species & $\begin{array}{c}\text { Modified } \\
\text { nucleoside }\end{array}$ & Wild type & $\operatorname{sit} 4 \Delta$ & 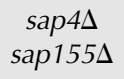 & sap185s & sap190s & 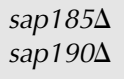 & $\operatorname{trm} 9 \Delta$ & kti14-1 \\
\hline \multirow{6}{*}{ tRNA Glu } & $\Psi$ & 1.00 & 1.00 & 1.00 & 1.00 & 1.00 & 1.00 & 1.00 & 1.00 \\
\hline & $\mathrm{m}^{5} \mathrm{C}$ & 1.00 & 0.95 & 1.13 & 0.98 & 1.00 & 0.88 & 0.95 & 0.90 \\
\hline & $\mathrm{m}^{5} \mathrm{U}$ & 1.00 & 0.92 & 1.00 & 0.99 & 0.99 & 0.91 & 0.95 & 0.94 \\
\hline & $\mathbf{s}^{2} \mathrm{U}$ & - & + & - & - & - & + & - & + \\
\hline & $\mathrm{mcm}^{5} \mathrm{~s}^{2} U$ & 1.00 & $<\mathbf{0 . 0 2}^{\mathrm{a}}$ & 1.10 & 1.11 & 1.05 & $<\mathbf{0 . 0 1}^{\text {a }}$ & $<\mathbf{0 . 0 3}^{\mathrm{a}}$ & 0.10 \\
\hline & $n c m^{5} s^{2} U$ & - & - & - & - & - & - & + & - \\
\hline \multirow[t]{9}{*}{$\operatorname{tRNA} A_{\cup C \cup}^{A r g}$} & $\Psi$ & 1.00 & 1.00 & 1.00 & 1.00 & 1.00 & 1.00 & 1.00 & 1.00 \\
\hline & $\mathrm{m}^{1} \mathrm{~A}$ & 1.00 & 1.00 & 0.87 & 0.99 & 0.94 & 1.05 & 1.04 & 1.03 \\
\hline & $\mathrm{m}^{5} \mathrm{U}$ & 1.00 & 1.08 & 0.99 & 1.00 & 0.99 & 1.12 & 0.98 & 1.04 \\
\hline & $\mathrm{mcm}^{5} \mathrm{U}$ & 1.00 & $<\mathbf{0 . 0 2}^{\mathrm{a}}$ & 1.08 & 1.02 & 0.98 & $<0.02^{\mathrm{a}}$ & $<\mathbf{0 . 0 3}^{\mathrm{a}}$ & 0.09 \\
\hline & $\mathrm{ncm}^{5} \mathrm{U}$ & - & - & - & - & - & - & + & - \\
\hline & $m^{1} G$ & 1.00 & 0.77 & 1.07 & 1.02 & 1.03 & 0.70 & 1.01 & 0.93 \\
\hline & $\mathrm{m}^{2} \mathrm{G}$ & 1.00 & 0.77 & 1.07 & 1.02 & 1.03 & 0.70 & 1.02 & 0.93 \\
\hline & $\mathrm{m}^{2}{ }_{2} \mathrm{G}$ & 1.00 & 0.77 & 1.06 & 1.02 & 1.03 & 0.70 & 1.03 & 0.93 \\
\hline & $t^{6} A$ & 1.00 & 1.10 & 0.95 & 1.05 & 1.01 & 1.08 & 0.93 & 1.13 \\
\hline \multirow[t]{6}{*}{ tRNA ${ }_{\cup G G}^{\text {Pro }}$} & $\Psi$ & 1.00 & 1.00 & 1.00 & 1.00 & 1.00 & 1.00 & 1.00 & 1.00 \\
\hline & $\mathrm{ncm}^{5} \mathrm{U}$ & 1.00 & $<\mathbf{0 . 0 1}^{\mathrm{a}}$ & 1.14 & 1.07 & 1.10 & $<\mathbf{0 . 0 2}^{\mathrm{a}}$ & 0.92 & 0.12 \\
\hline & $m^{1} A+m^{5} C^{b}$ & 1.00 & 1.15 & 1.02 & 1.08 & 1.04 & 1.15 & 1.00 & 1.04 \\
\hline & $\mathrm{Cm}$ & 1.00 & 0.75 & 1.10 & 1.06 & 1.11 & 0.57 & 1.02 & 1.04 \\
\hline & $m^{5} U+m^{7} G^{c}$ & 1.00 & 1.26 & 1.01 & 1.13 & 1.08 & 1.38 & 1.00 & 1.07 \\
\hline & $m^{1} G$ & 1.00 & 1.02 & 1.06 & 1.06 & 1.05 & 0.97 & 0.95 & 1.02 \\
\hline
\end{tabular}

( $\Psi)$ Pseudouridine; $\left(\mathrm{m}^{5} \mathrm{C}\right)$ 5-methylcytidine; $\left(\mathrm{m}^{5} \mathrm{U}\right)$ 5-methyluridine; $\left(\mathrm{s}^{2} \mathrm{U}\right)$ 2-thiouridine; $\left(\mathrm{mcm}^{5} \mathrm{~s}^{2} \mathrm{U}\right)$ 5-methoxycarbonylmethyl-2-thiouridine; $\left(n \mathrm{~nm}^{5} \mathrm{~s}^{2} \mathrm{U}\right)$ 5-carbamoylmethyluridine-2-thiouridine; $\left(\mathrm{m}^{1} \mathrm{~A}\right)$ 1-methyladenosine; $\left(\mathrm{m}^{1} \mathrm{G}\right)$ 1-methylguanosine; $\left(\mathrm{m}^{2} \mathrm{G}\right) \mathrm{N}^{2}$-methylguanosine; $\left(\mathrm{m}^{2}{ }_{2} \mathrm{G}\right)$ $\mathrm{N}^{2}, \mathrm{~N}^{2}$-dimethylguanosine; $\left(\mathrm{t}^{6} \mathrm{~A}\right) \mathrm{N}^{6}$-threonylcarbamoyladenosine; $\left(\mathrm{mcm}^{5} \mathrm{U}\right)$ 5-methoxycarbonylmethyluridine; $(\mathrm{Cm}) 2^{\prime}-\mathrm{O}$-methylcytidine; $\left(m^{7} G\right)$ 7-methylguanosine; and $\left(\mathrm{ncm}^{5} \mathrm{U}\right)$ 5-carbamoylmethyluridine; "- " indicates no detection of $\mathrm{s}^{2} \mathrm{U}$, $\mathrm{ncm} \mathrm{cm}^{2} \mathrm{U}, \mathrm{or}_{\mathrm{ncm}}^{5} \mathrm{U}$; and " $+^{\prime \prime}$ indicates presence of $\mathrm{s}^{2} \mathrm{U}, \mathrm{ncm}^{5} \mathrm{~s}^{2} \mathrm{U}$, or $\mathrm{ncm}^{5} \mathrm{U}$. Pseudouridine $(\Psi)$, present three times in $\mathrm{TRNA}_{\mathrm{mcm}}^{\mathrm{Glu} \mathrm{s}^{2} U \mathrm{UC}^{\prime}}$, three times in $\mathrm{tRNA}_{\mathrm{mcm}}^{\mathrm{Arg} U C \mathrm{U}^{\prime}}$, and four

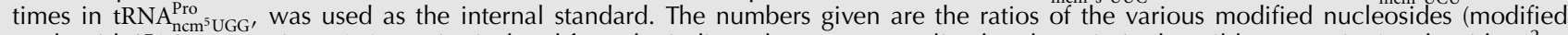
nucleoside/ $\Psi$ ) in respective tRNA species isolated from the indicated mutant normalized to the ratio in the wild-type strain. Nucleosides $\mathrm{s}^{2} \mathrm{U}$,

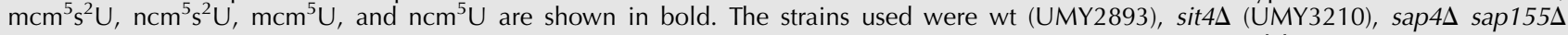

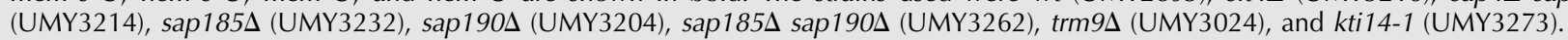

${ }^{\mathrm{a}}$ Detection limit.

${ }^{b} m^{1} A$ comigrated with $m^{5} \mathrm{C}$.

${ }^{\mathrm{C}} \mathrm{m}^{5} \mathrm{U}$ comigrated with $\mathrm{m}^{7} \mathrm{G}$

The function of the Sit4 protein is regulated by various sit4-associated proteins (SAPs): Sap185, Sap190, Sap4, and Sap155 (Luke et al. 1996). While deletion of SAP185 or SAP190 individually does not affect zymocin resistance, a strain lacking both Sap190 and Sap185 proteins displays class II zymocin resistance (Jablonowski et al. 2001a, 2004).

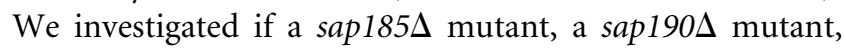

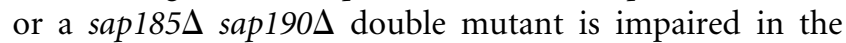
formation of $\mathrm{mcm}^{5} \mathrm{~s}^{2} \mathrm{U}$. No defect was observed in the

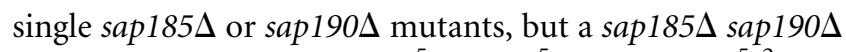
double mutant lacked $\mathrm{mcm}^{5} \mathrm{U}, \mathrm{ncm}^{5} \mathrm{U}$, and $\mathrm{mcm}^{5} \mathrm{~s}^{2} \mathrm{U}$ in purified tRNA $\mathrm{mcm}^{5} \mathrm{UCU}^{\mathrm{Arg}}, \mathrm{tRNA}_{\mathrm{ncm}^{5} \mathrm{UGG}}^{\mathrm{Pro}}$, and $\mathrm{tRNA}_{\mathrm{mcm}}^{\mathrm{Glu} \mathrm{s}^{2} \mathrm{UUC}}$, respectively (Table 3 ). On the contrary, a strain deleted for genes encoding the other two Sit4-associated proteins (sap4 $\Delta$

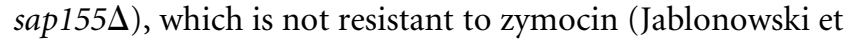
al. 2001a), did not show any defect in wobble uridine modification (Table 3). The formation of $\mathrm{s}^{2}$ group is not

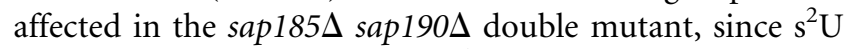
was detected in purified tRNA $\mathrm{mcm}^{\mathrm{Glu} \mathrm{s}^{2} \mathrm{UUC}}$ (Table 3).
A mutation in the KTI14 gene causes class II zymocin resistance (Butler et al. 1994). The KTI14 gene was found to be allelic to HRR25 (Mehlgarten and Schaffrath 2003), which encodes a casein kinase homolog involved in diverse cellular processes, for example, DNA repair, vesicular trafficking, calcineurin signaling, ribosome maturation, and chromosome segregation (Hoekstra et al. 1991; DeMaggio et al. 1992; Ho et al. 1997; Murakami et al. 1999; Kafadar et al. 2003; Petronczki et al. 2006; Schafer et al. 2006). Monitoring the wobble uridine modifications in tRNA isolated from the ktil4-1 mutant revealed a decreased level of $\mathrm{mcm}^{5} \mathrm{~s}^{2} \mathrm{U}, \mathrm{mcm}^{5} \mathrm{U}$, and $\mathrm{ncm}^{5} \mathrm{U}$ nucleosides ( $\sim 10 \%$ of wild type) in $\mathrm{tRNA}_{\mathrm{mcm}}^{\mathrm{Glu} \mathrm{s}^{2} \mathrm{UUC}}$, $\mathrm{tRNA}_{\mathrm{mcm}^{5} \mathrm{UCU}}^{\mathrm{Arg}}$, and $\mathrm{tRNA} \mathrm{ncm}^{\mathrm{Pro}} \mathrm{UGG}^{5}$, respectively (Table 3). A deletion of the KTI14 gene abolished the formation of $\mathrm{mcm}^{5} \mathrm{U}$ and $\mathrm{mcm}^{5} \mathrm{~s}^{2} \mathrm{U}$ in total tRNA (Table 1). Thiolation at position 2 is not affected in the kti14-null and the kti14-1 mutants, since $s^{2} U$ was detected in both total tRNA and purified $\mathrm{tRNA}_{\mathrm{mcm}}^{\mathrm{Glu} \mathrm{s}^{2} \mathrm{UUC}}$ (Tables 1, 3). 
A

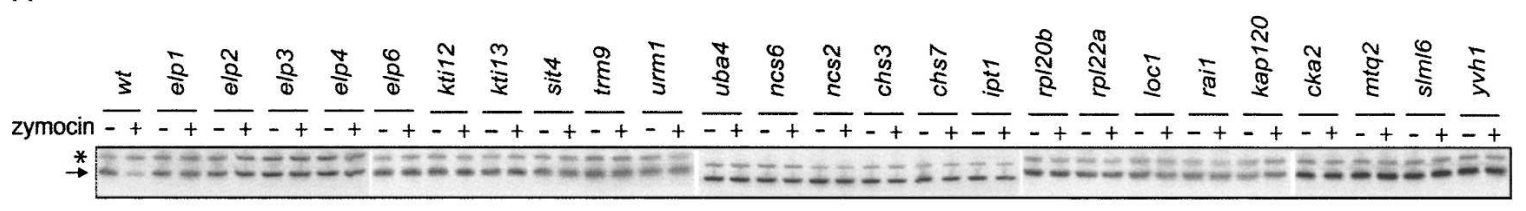

B

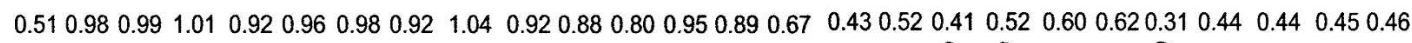

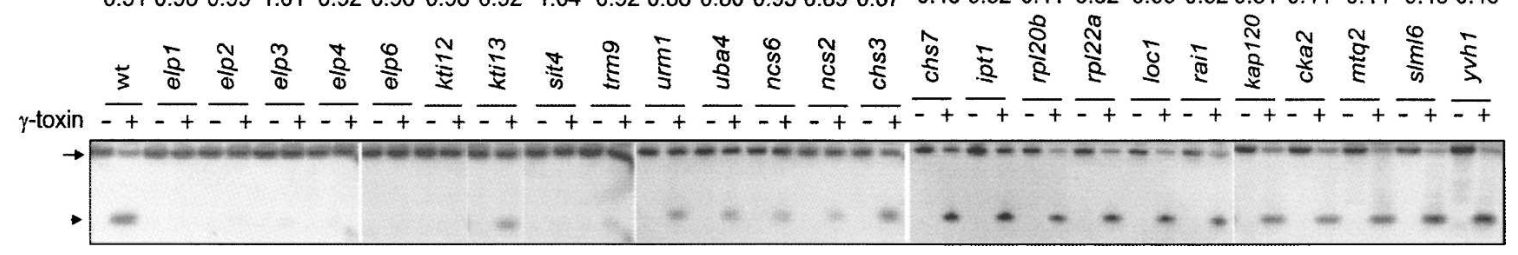

FIGURE 3. Reactivity of tRNA Glu from different strains to zymocin (in vivo) and $\gamma$-toxin (in vitro). (A) Crude zymocin was added to log-phase cultures of indicated strains. Total RNA was isolated and the level of tRNA Glu wU was analyzed by Northern blot using oligonucleotides specific for $\left.{ }^{*}\right)$ tRNA $_{\mathrm{CGA}}^{\text {Ser }}$ and (arrow) tRNA Glu (B) Total RNA from indicated strains was mixed with purified $\gamma$-toxin-GST at a concentration of $5 \mathrm{nM}$ and incubated for $15 \mathrm{~min}$ at $30^{\circ} \mathrm{C}$. The level of tRNA ${ }_{U U C}^{\text {Glu }}$ was analyzed by Northern blot using oligonucleotides specific for tRNA Glu (Aurowhead) The $3^{\prime}$ cleavage product of tRNA Glu (Arrow) The full-length tRNA Glu signals were quantified, and the ratio between $\gamma$-toxin treated and untreated samples was calculated and shown in the graph. All strains were from the S. cerevisiae deletion collection.

The KTI5 mutant displays resistance to both exogenous zymocin and intracellular $\gamma$-toxin expression. Interestingly, its resistance to exogenous zymocin is a dominant phenotype (Butler et al. 1991a). In the effort to identify the mutation in this strain, a recessive temperature-sensitive $(t s)$ phenotype was found to be tightly linked to zymocin resistance. By complementing this ts phenotype, we found that KTI5 is allelic to the KTI11 gene (data not shown). When the KTI5 allele was sequenced, a G-to-C mutation was observed at position 80 in the KTI11 gene, which results in cysteine-to-serine substitution at residue 27 (data not shown). Cys27 is one of the four cysteines in the Kti11 protein that form a zinc-binding domain (Sun et al. 2005). Similar to a kti11 mutant, a KTI5 mutant lacked $\mathrm{mcm}^{5} \mathrm{~s}^{2} \mathrm{U}$ and $\mathrm{mcm}^{5} \mathrm{U}$ in total tRNA (Table 1). When the KTI5 mutant was crossed with a wild-type strain, the resulting diploid strain displayed the identical modification defect as a haploid KTI5 mutant strain (Table 1), demonstrating that the modification defect in KTI5 is also dominant. In addition to the wobble uridine modification in tRNA, the Ktil1 protein is required for the synthesis of diphthamide, a post-translationally modified histidine residue present in the elongation factor 2 (eEF2) in eukaryotes (Liu and Leppla 2003). Diphthamide is the target of diphtheria toxin and Pseudomonas exotoxin A (Collier 2001). Similar to a ktil1 mutant, a KTI5 mutant was resistant to diphtheria toxin (data not shown), suggesting that the zinc-binding motif in the Ktill protein is important for both tRNA modification and diphthamide biosynthesis.

\section{DISCUSSION}

The formation of $\mathrm{mcm}^{5}$ and $\mathrm{ncm}^{5}$ groups at wobble uridines requires many gene products (Huang et al. 2005). In this study, we report the screening of a yeast homozygous diploid deletion collection for mutants defective in $\mathrm{mcm}^{5} \mathrm{~s}^{2} \mathrm{U}$ formation. Because lack of $\mathrm{mcm}^{5}$ modification in substrate tRNAs causes zymocin resistance ( $\mathrm{Lu}$ et al. 2005), which is easy to score, the initial screen was based on this phenotype. In the collection of 4826 deletion mutant strains, 63 mutants were found to be resistant to zymocin. Transfer RNA from these zymocin-resistant mutants was further analyzed by HPLC to identify mutants impaired in the formation of $\mathrm{mcm}^{5} \mathrm{~s}^{2} \mathrm{U}$. The validity of the screen was confirmed by the identification of deletion strains known to be affected in the synthesis of $\mathrm{mcm}^{5}$, that is, elp1-elp4, elp6, kti12, kti13, and trm9 (null strains of elp5 and kti11 are not present in the deletion collection). Interestingly, we also identified additional mutants that are affected in the formation of the $\mathrm{mcm}^{5}$ (sit4) or $\mathrm{s}^{2}$ group (urm1, uba4, ncs2, and yor 251c). Analysis of other previously known class II zymocin-resistant mutants showed that the KTI5 is a dominant allele of KTI11 and that KTI5, kti14 mutants

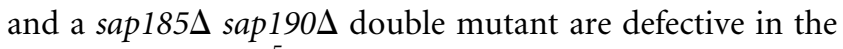
formation of $\mathrm{mcm}^{5} \mathrm{U}$.

\section{Involvement of a protein phosphatase and a kinase in the formation of $\mathrm{mcm}^{5}$ and $\mathrm{ncm}^{5}$ groups at wobble uridines}

The Sit4 protein is a type 2A-related serine-threonine phosphatase involved in the regulation of cell growth and proliferation (for review, see Jiang 2006). Sit4 is required for proper $G_{1}$ to $S$-phase transition, plays an important role in nutrient response mediated by TOR pathway, and modulates functions mediated by protein kinase $\mathrm{C}$ ( $\mathrm{Pkclp}$ ) including cell wall and actin cytoskeleton organization (Sutton et al. 1991; Di Como and Arndt 1996; Angeles de 
la Torre-Ruiz et al. 2002). The function of the Sit4 protein is regulated, at least partly, by various Sit4-associated proteins (Sap185, Sap190, Sap155, and Sap4) (Luke et al. 1996). Similar to a sit4 mutant, cells lacking Sap185p and Sap190p display class II zymocin resistance (Jablonowski et al. 2001a, 2004). Consistently, a sap185, sap190 double mutant displayed the same defect in the synthesis of the $\mathrm{mcm}^{5}$ and $\mathrm{ncm}^{5}$ groups as a sit4 mutant (Table 3 ). On the contrary, a strain with deletions of the genes encoding the other two Sit4-associated proteins Sap4p and Sap 155p, which do not cause zymocin resistance (Jablonowski et al. 2001a), had no effect on $\mathrm{mcm}^{5}$ and $\mathrm{ncm}^{5}$ side-chain formation. This suggests that the role of Sit4p in tRNA modification is modulated by or acting through the association with Sap185p and Sap190p.

In addition to the Sit4 phosphatase, we also identified the kinase Kti14p in the present study. Consistent with its class II zymocin resistance (Butler et al. 1994), the kti14-1 mutant was found to be defective in the formation of $\mathrm{mcm}^{5}$ and $\mathrm{ncm}^{5}$ side chains (Table 3). Kti14p/ Hrr25p, a homolog of mammalian casein kinase $1 \delta$, is involved in diverse cellular events including DNA repair (Hoekstra et al. 1991; DeMaggio et al. 1992; Murakami et al. 1999; Ho et al. 2002; Kafadar et al. 2003; Petronczki et al. 2006; Schafer et al. 2006). Interestingly, a kti14-2 mutant, which is zymocin resistant, is not hypersensitive to the DNA damage reagent drug methylmethane sulfonate (MMS) like other kti14 alleles, suggesting that the function of the Kti14 protein in DNA repair is uncoupled from its function in zymocin action (or rather tRNA modification) (Mehlgarten and Schaffrath 2003). So how does defective Kti14p lead to impaired tRNA modification? Given that the Kti14 protein physically interacts with proteins in the core Elongator complex (Elp2 and Elp3 proteins) and with the Sit4pSap185p-Sap190p complex (Ho et al. 2002; Schafer et al. 2003; Gavin et al. 2006), it is tempting to propose that Sit4 and Kti14 proteins may cooperate to regulate the phosphorylation status of proteins required for the formation of $\mathrm{mcm}^{5}$ and $\mathrm{ncm}^{5}$ side chains. One such candidate substrate that links tRNA modification to the Sit4p/Kti14p regulation is the Elp1 protein. It has been shown that the phosphorylation status of Elp1 protein is affected by Sit4p, Sap185p, Sap190p, and Kti12p (Jablonowski et al. 2004). The dephosphorylation of Elplp depends on the Sit4 phosphatase and two of its associated proteins, Sap185p and Sap190p, while Kti12p can antagonize Sit4-dependent dephosphorylation of Elplp (Jablonowski et al. 2004). Kti12p is associated with the Elongator complex (Frohloff et al. 2001, 2003; Fichtner et al. 2002b, 2003; Petrakis et al. 2005; Krogan et al. 2006). Lack of Kti12p causes class II zymocin resistance (Frohloff et al. 2001) and abolishes the formation of $\mathrm{mcm}^{5}$ and $\mathrm{ncm}^{5}$ side chains (Huang et al. 2005). Presumably, the modification defect in the sit4 mutant is elicited through the deregulation of Elp1p phosphorylation, as in the case of the kti12 mutant (Jablonowski et al. 2004). However, it remains to be seen if the phosphorylation of Elp1 involves Kti14p and Kti12p and whether dephosphorylation of Elp1p is a direct effect of Sit4p.

In accordance with the role of Trm9 in methylation (Kalhor and Clarke 2003), modified nucleosides $\mathrm{mcm}^{5} \mathrm{~s}^{2} \mathrm{U}$ and $\mathrm{mcm}^{5} \mathrm{U}$ were absent in $\mathrm{tRNA}_{\mathrm{mcm}^{5} \mathrm{~s}^{2} \mathrm{UUC}}^{\mathrm{Glu}}$ and $\mathrm{tRNA}_{\mathrm{mcm}{ }^{5} \mathrm{UCU}}^{\mathrm{Arg}}$, respectively, in a trm9-null mutant (Table 3). Interestingly, in the trm 9 mutant, we noticed the occurrence of $\mathrm{ncm}^{5} \mathrm{~s}^{2} \mathrm{U}$ in $\mathrm{tRNA}_{U U \mathrm{UC}}^{\mathrm{Glu}}$ and $\mathrm{ncm}^{5} \mathrm{U}$ in tRNA $\mathrm{ACH}$, instead of the expected $\mathrm{cm}^{5} \mathrm{~s}^{2} \mathrm{U}$ and $\mathrm{cm}^{5} \mathrm{U}$ nucleosides (Kalhor and Clarke 2003). This surprising finding presently is being investigated in our laboratory.

\section{Proteins involved in the formation of the 2-thio group on wobble uridines}

All three $\gamma$-toxin target tRNAs, $\mathrm{tRNA}_{\mathrm{mcm} \mathrm{s}^{2} \mathrm{UUC}}^{\mathrm{Glu}}, \mathrm{tRNA}_{\mathrm{mcm} \mathrm{s}^{5} \mathrm{~s}^{2} \mathrm{LUU}}^{\mathrm{Lys}}$, and $\mathrm{tRNA}_{\mathrm{mcm}}^{\mathrm{Gln} \mathrm{s}^{2} \mathrm{UUG}}$, contain a 2-thio modification at the wobble uridine. Earlier, seven proteins were known to be involved in the thiolation of cytosolic tRNAs in the yeast S. cerevisiae (Nakai et al. 2004, 2007; Björk et al. 2007). The NFS1 gene encodes a cysteine desulfurase involved in Fe-S cluster biogenesis. An $n f s 1$ mutant has a defect in 2-thio modification of both mitochondrial and cytoplasmic tRNAs (Nakai et al. 2004). Most likely, Nfs1 serves as sulfur donor for tRNA thiolation, a function shared with its bacterial homolog IscS (Zheng et al. 1998). Thiolation of cytosolic tRNAs is iron-sulfur (Fe/S) protein dependent and requires the mitochondrial and cytosolic Fe/S cluster assembly machineries termed ISC and CIA. Three components of CIA (Cfd1, Nbp35, and Cia1) and two mitochondria scaffold proteins (Isu1 and Isu2) are required for the 2-thio modification of the cytosolic tRNAs but are dispensable for thiolation of the mitochondrial tRNAs (Nakai et al. 2007). Recently, the Ncs6/Tuc1 protein was shown to be required for 2-thio modification of cytosolic tRNAs, and based on its homology with the bacterial TtcA protein, which is required for 2-thiocytidine synthesis, Ncs6/Tuc1 was proposed to be responsible for making 2thiouridine in yeast (Björk et al. 2007).

In the present screen of the yeast gene deletion collection, we identified four mutants, urm $1, u b a 4, n c s 2$, and $n c s 6 / t u c 1$, which lacked the 2-thio modification on wobble uridines. Another mutant, yor251c, shows a reduced level of $\mathrm{s}^{2}$-containing modified uridines. Strains with deletions of the NFS1, CFD1, NBP35, or CIA1 genes were not found as they are nonviable, and the ISU1 and ISU2 are functionally redundant (Nakai et al. 2001, 2007; Gerber et al. 2004). Urm1 and Uba4 proteins function in the urmylation pathway, one of the ubiquitin-like protein conjugation systems in S. cerevisiae (Furukawa et al. 2000). Ubiquitin and ubiquitin-like modifier proteins are attached covalently to target proteins and alter their function and localization (Hochstrasser 2000; Schnell and Hicke 2003). Although the urmylation pathway has been suggested to be involved in 
multiple processes, for example, invasive growth, budding, and antioxidant stress response, only one target protein (Ahp1p) has been identified so far (Goehring et al. 2003). It is possible that any of the Ncs2, Ncs6/Tuc1 proteins or components of the $\mathrm{Fe} / \mathrm{S}$ cluster assembly machineries ISC and CIA may function only after being urmylated.

Lack of the $\mathrm{mcm}^{5}$ side chain in $\mathrm{tRNA}_{\mathrm{mcm}}^{\mathrm{Glu}} \mathrm{s}^{2} \mathrm{UUC}$, $\mathrm{tRNA}_{\mathrm{mcm}^{5} \mathrm{~s}^{2} \mathrm{UUU}}^{\mathrm{Ls}}$, and $\mathrm{tRNA}_{\mathrm{mcm}^{5} \mathrm{~s}^{2} \mathrm{GUG}}^{\mathrm{Gln}}$ causes inefficient cleavage by $\gamma$-toxin and renders cells resistant to zymocin (Lu et al. 2005). Mutants lacking the $\mathrm{s}^{2}$ group displayed a weak $\gamma$-toxin resistance, consistent with the observation that 2-thio modification on tRNAs is also required for efficient $\gamma$-toxin cleavage (Lu et al. 2008).

In conclusion, by screening 4826 yeast strains with deletions in nonessential genes, we have identified gene products involved in the formation of the $\mathrm{mcm}^{5} \mathrm{~s}^{2} \mathrm{U}$ nucleoside at wobble positions in tRNA. It is still possible that additional genes representing essential genes in yeast are required for the formation of the $\mathrm{mcm}^{5} \mathrm{~s}^{2} \mathrm{U}$ nucleoside. The number of proteins so far identified to be required for the formation of the $\mathrm{mcm}^{5}$ side chain and the $\mathrm{s}^{2}$ group is surprisingly large (Fig. 4). Knowing that a kinase, a phosphatase, and a ubiquitin-like protein-modifying system is required for formation of $\mathrm{mcm}^{5} \mathrm{~s}^{2} \mathrm{U}$ suggests that biosynthesis of $\mathrm{mcm}^{5} \mathrm{~s}^{2} \mathrm{U}$ is a complex process likely to involve regulation by signal transduction.

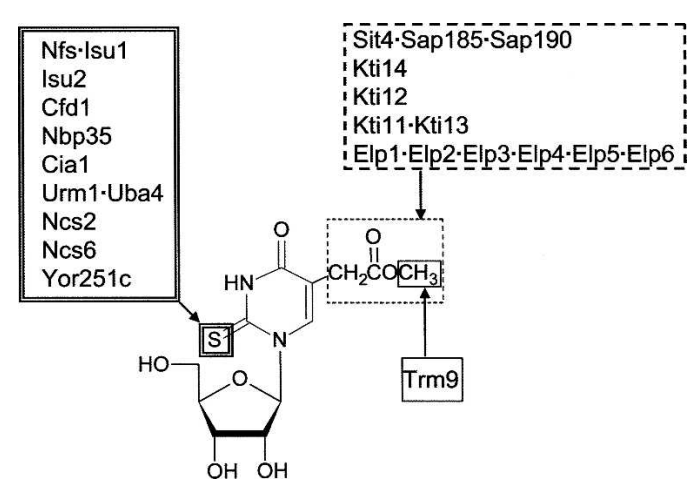

FIGURE 4. Proteins involved in the formation of wobble nucleoside $\mathrm{mcm}^{5} \mathrm{~s}^{2} \mathrm{U}$. So far 14 and 11 gene products have been found to be involved in the formation of the $\mathrm{mcm}^{5}$ and $\mathrm{s}^{2}$ group of $\mathrm{mcm}^{5} \mathrm{~s}^{2} \mathrm{U}$, respectively. Note that the former group of gene products is also involved in the formation of $n \mathrm{~cm}^{5} \mathrm{U}$. Trm9p is required for the last step, formation of the esterified methyl constituent in $\mathrm{mcm}^{5} \mathrm{U}$ and $\mathrm{mcm} \mathrm{s}^{2} \mathrm{U}$. Physical interaction between proteins is indicated by a dot (Luke et al. 1996; Otero et al. 1999; Wittschieben et al. 1999; Furukawa et al. 2000; Krogan and Greenblatt 2001; Winkler et al. 2001; Ho et al. 2002; Gavin et al. 2006; Krogan et al. 2006). Other interactions not shown in the figure are Kti14p, Kti12p, and Ktil1p, which all interact with subunits of Elongator subcomplex (Elplp, Elp2p, Elp3p) (Fichtner et al. 2002a, 2003; Frohloff et al. 2003; Schafer et al. 2003; Petrakis et al. 2005; Gavin et al. 2006; Krogan et al. 2006). There is also interaction between the Sit 4 complex and Kti14p (Ho et al. 2002). Note that Nfs1p, Isulp, and Isu2p are located in the mitochondria. Figure modified from Lu (2007).

\section{MATERIALS AND METHODS}

\section{Strains, medium, and genetic procedure}

Yeast media, transformation, and genetic procedures have been described (Burke et al. 2000). The yeast cells were grown in YEPD medium at $30^{\circ} \mathrm{C}$, unless otherwise stated. All the yeast strains used in this study, except those from the yeast diploid homozygous deletion collection (Research Genetics), are listed in Table 4.

A deletion of the SIT4 gene in S. cerevisiae is lethal in strains with a W303 background but not in strains with an S288C background, which is attributed to a polymorphic gene, SSD1. Strains with a W303 background carry the ssd1-d allele, while strains with an S288C background carry the SSD1-v1 allele (Sutton et al. 1991). To make a deletion of the SIT4 gene in a W303 background, the SSD1-v1 allele was introduced into UMY2893 (W303-1B SUP4) (Huang et al. 2005) by transforming a linearized pRS306-SSD1-v1 plasmid, generating UMY3292 (W303-1B SUP4 ssd1-d::URA3::SSD1-v1). The strain UMY3292 was crossed with CY3938 (W303-1A sit4::HIS3 SSD1-v1) (Luke et al. 1996), and the resulting diploid was sporulated to generate UMY3210 (W303-1B sit4::HIS3 SSD1-v1 SUP4). UMY3204 (W303-1B sap190::TRP1 SSD1-v1 SUP4) and UMY3214 (W3031B sap4::LEU2 sap155::HIS3 SSD1-v1 SUP4) were constructed in a similar way from the crosses between UMY3292 and CY4380 (W303-1A sap190:: TRP1 SSD1-v1) (Luke et al. 1996) or CY5220 (W303-1A sap4::LEU2 sap155::HIS3 SSD1-v1) (Luke et al. 1996), respectively. The strain UMY3292 was crossed with CY4029 (W303-1A SSD1-v1), and the resulting diploid was sporulated to generate UMY3200 (W303-1A SSD1-v1 SUP4) and UMY3201 (W303-1B SSD1-v1 SUP4). To delete the SAP185 gene, chromosomal DNA from the corresponding null mutant in the yeast deletion collection (Research Genetics) was used as template to amplify DNA fragments containing the KanMX4 cassette and 300-400 nucleotides (nt) of flanking sequences. The PCR product was transformed into strains UMY3200 and UMY3201. Transformants were selected on YEPD plates containing $200 \mu \mathrm{g} / \mathrm{mL}$ G418, and the deletion of the SAP185 gene was confirmed by PCR. The strains generated were UMY3231 (W303-1A SSD1-v1 SUP4 sap185::KanMX4) and UMY3232 (W303-1B SSD1-v1 SUP4 sap185::KanMX4). The strain UMY3231 was crossed with UMY3204, and the resulting diploid was sporulated to generate UMY3262 (W303-1B SSD1-v1 SUP4 sap185::KanMX4 sap190::TRP1).

The homozygous diploid strains deleted for each nonessential gene were from Research Genetics. The control strain used in the zymocin resistance assay, with an isogenic genetic background,

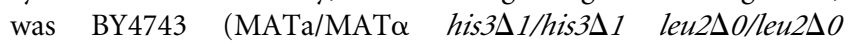

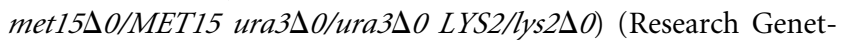
ics). The mutations in sit4, trm9, uba4, ncs2, ncs6l tucl, and yor251c in the yeast deletion collection were confirmed by PCR. The urm $1 \Delta$ strain from the deletion collection was found to contain wild-type alleles of URM1. To delete the URM1 gene, oligonucleotides containing 50-nt homology with the flanking sequences of URM1 gene were used to amplify the KanMX6 cassette (Longtine et al. 1998). The PCR product was transformed into strain UMY3385 (W303-1A SSD1-v1) or UMY3386 (W3031B SSD1-v1), and transformants were selected on YEPD plates containing $200 \mu \mathrm{g} / \mathrm{mL}$ G418. UMY3385 and UMY3386 were segregants in a cross between CY4029 and CY4102 (W303-1B 
TABLE 4. Yeast strains used in this study

\begin{tabular}{|c|c|c|}
\hline Yeast strain & Description & Source \\
\hline \multicolumn{3}{|l|}{ K. lactis } \\
\hline 2105-1D & MATa leu ade1 ade2 pGKL1 pGKL2 & Gunge and Sakaguchi (1981) \\
\hline \multicolumn{3}{|l|}{ S. cerevisiae } \\
\hline ARB5 & MAT $\alpha$ leu2-3,112 his3-11,15 KTI5 & Butler et al. (1991a) \\
\hline ARB97 & MAT $\alpha$ leu2-3,112 his3-11,15 kti14-1 & Butler et al. (1994) \\
\hline BY4743 & 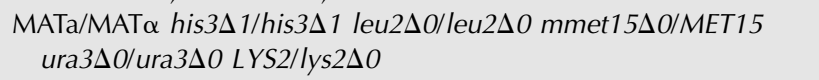 & Research Genetics \\
\hline W303-1A & MATa leu2-3,112 trp1-1 can1-100 ura3-1 ade2-1 his3-11,15 & Fiorentini et al. (1997) \\
\hline W303-1B & MAT $\alpha$ leu2-3,112 trp1-1 can1-100 ura3-1 ade2-1 his3-11,15 & Fiorentini et al. (1997) \\
\hline CY3938 & As W303-1A, but SSD1-v1 sit4:: HIS3 & Luke et al. (1996) \\
\hline CY4029 & As W303-1A, but SSD1-v1 & Luke et al. (1996) \\
\hline CY4102 & As W303-1B, but SSD1-v1 cln3::URA3 & Luke et al. (1996) \\
\hline CY4380 & As W303-1B, but SSD1-v1 sap190:: TRP1 & Luke et al. (1996) \\
\hline CY5220 & As W303-1B, but SSD1-v1 sap4::LEU2 sap155::HIS3 & Luke et al. (1996) \\
\hline UMY2893 & As W303-1B, but SUP4 & Huang et al. (2005) \\
\hline UMY3024 & As W303-1B, but SUP4 trm9::KanMX4 & Lu et al. (2005) \\
\hline UMY3200 & As W303-1A, but SUP4 SSD1-V1 & This study \\
\hline UMY3201 & As W303-1B, but SUP4 SSD1-v1 & This study \\
\hline UMY3204 & As W303-1B, but SUP4 SSD1-v1 sap190:: TRP1 & This study \\
\hline UMY3210 & As W303-1B, but SUP4 SSD1-v1 sit4::HIS3 & This study \\
\hline UMY3214 & As W303-1B, but SUP4 SSD1-v1 sap4::LEU2 sap155::HIS3 & This study \\
\hline UMY3231 & As W303-1A, but SUP4 SSD1-v1 sap185::KanMX4 & This study \\
\hline UMY3232 & As W303-1B, but SUP4 SSD1-v1 sap185::KanMX4 & This study \\
\hline UMY3262 & As W303-1B, but SUP4 SSD1-v1 sap185::KanMX4 sap190:: TRP1 & This study \\
\hline UMY3273 & As W303-1A, but kti14-1 & This study \\
\hline UMY3275 & As W303-1A, but KTI5 & This study \\
\hline UMY3276 & As W303-1B, but KTI5 & This study \\
\hline UMY3292 & As W303-1B, but SUP4 ssd1-d::URA3::SSD1-v1 & This study \\
\hline UMY3323 & As W303-1B, but kti14-1 ssd1-d::URA3::SSD1-v1 & This study \\
\hline UMY3326 & As W303-1B, but SSD1-v1 Kti14-1 & This study \\
\hline UMY3385 & As W303-1A, but SSD1-v1 & This study \\
\hline UMY3386 & As W303-1B, but SSD1-v1 & This study \\
\hline UMY3464 & Diploid between UMY3275 and W303-1B & This study \\
\hline UMY3387 & Diploid between UMY3385 and UMY3386 & This study \\
\hline UMY3408 & As W303-1B, but SSD1-v1 Kti14::KanMX6 & This study \\
\hline UMY3429 & As W303-1A, but SSD1-v1 urm 1::KanMX6 & This study \\
\hline UMY3430 & As W303-1B, but SSD1-v1 urm 1::KanMX6 & This study \\
\hline UMY3546 & Diploid between UMY3429 and UMY3430 & This study \\
\hline UMY3548 & As BY4743, but URM1/urm 1::KanMX6 & This study \\
\hline UMY3549 & 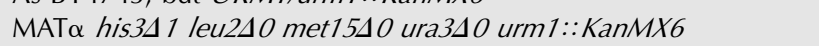 & This study \\
\hline UMY3552 & 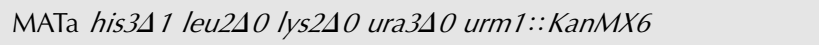 & This study \\
\hline UMY3553 & Diploid between UMY3549 and UMY3552 & This study \\
\hline
\end{tabular}

cln3::URA3 SSD1-v1). Deletion of the URM1 gene was confirmed by PCR, and the strains generated were UMY3429 (W303-1A urm1::KanMX6 SSD1-v1) and UMY3430 (W303-1B urm1:: KanMX6 SSD1-v1). A diploid strain, UMY3546, was obtained by crossing UMY3429 with UMY3430. To delete the URM1 gene in the BY4743 background, the chromosomal DNA of UMY3430 was used as template to amplify DNA fragments containing the KanMX6 cassette and $200 \mathrm{nt}$ of flanking sequences of the URM1 gene. The PCR product was transformed into BY4743, and transformants were selected on YEPD plates containing $200 \mu \mathrm{g} /$ $\mathrm{mL}$ G418. The deletion of the URM1 gene was confirmed by PCR, and the heterozygous URM1/urm1 deletion strain (UMY3548)

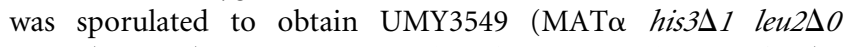

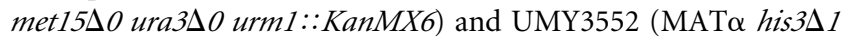

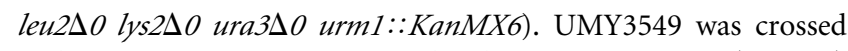

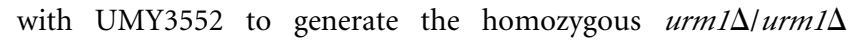
diploid UMY3553.

The strain ARB97 (MAT $\alpha$ leu2-3,112 his3-11,15 kti14-1) (Butler et al. 1994) was backcrossed with the strain W303-1A three times, generating UMY3273 (W303-1A ktil4-1). Similar to the sit4 mutant, the phenotypes of the ktil4 mutation were more severe in strains carrying the $s s d 1-d$ allele (data not shown). The SSD1- $v 1$ allele was introduced into UMY3273 by transforming a linearized pRS306-SSD1- $v 1$ plasmid, generating UMY3323 (W303-1A kti14-1 ssd1-d::URA3::SSD1-v1). The strain UMY3323 was crossed with UMY3386, and the resulting diploid was sporulated to generate UMY3326 (W303-1B kti14-1 SSD1-v1). To delete the KTI14 gene, oligonucleotides containing 50-nt homology with the flanking 
sequences of KTI14 gene were used to amplify the KanMX6 cassette (Longtine et al. 1998). The PCR product was transformed into strain UMY3387 (a diploid from the cross between UMY3385 and UMY3386), and transformants were selected on YEPD plates containing $200 \mu \mathrm{g} / \mathrm{mL}$ G418. Deletion of the KTI14 gene was confirmed by PCR, and the strain was sporulated to obtain UMY3408 (W303-1B kti14::KanMX6 SSD1-v1).

\section{Identification of the mutation in the dominant KTI5 mutant}

The KTI5 allele was moved into W303-1A by backcrossing the KTI5 mutant (ARB15) (Butler et al. 1991a) with W303-1A three times, generating UMY3275 (W303-1A, KTI5) and UMY3276 (W303-1B, KTI5). During the cross, a recessive temperaturesensitive (ts) phenotype cosegregated with the zymocin-resistant phenotype of KTI5 mutation. A genomic library was introduced into strain UMY3275, and plasmids complementing the ts phenotype were isolated. The restriction pattern and sequence analysis showed that all these complementing plasmids contained the KTI11 gene. The KTI5 allele in UMY3275 was PCR-amplified and sequenced. The heterozygous KTI5/wt diploid UMY3464 was generated by crossing UMY3275 with W303-1B.

\section{Zymocin resistance assay and intracellular induction of $\boldsymbol{\gamma}$-toxin}

The resistance to zymocin was analyzed using the killer eclipse assay (Kishida et al. 1996). The $S$. cerevisiae strains of interest were resuspended in autoclaved sterile water, yielding $0.15-0.2 \mathrm{OD}_{600}$ units. Five microliters of the cells was spotted on the YEPD plate. After the spots were dried, the K. lactis killer strain (2105-1D) (Gunge and Sakaguchi 1981) was inoculated on the edge of the spots. Clearing zones formed by the secreted zymocin were observed after incubation for $24 \mathrm{~h}$ at $30^{\circ} \mathrm{C}$. For some slowgrowing mutants, the incubation time was extended.

To test resistance to intracellular expression of $\gamma$-toxin, strains to be tested were transformed with the plasmid pRS316- $\mathrm{P}_{G A L 1^{-}} \boldsymbol{\gamma}$ toxin (pABY1472) (Lu et al. 2005) or pRS316- $\mathrm{P}_{\text {MET3- }} \boldsymbol{\gamma}$-toxin (pABY1728). Transformants were grown overnight in SC-Ura medium and resuspended in sterile water to a concentration of $3 \times 10^{6}$ cells $/ \mathrm{mL}$. For strains carrying the plasmid $\mathrm{pRS316- \textrm {P } _ { G A L 1 ^ { - } }}$ $\gamma$-toxin, 10-fold serial dilutions of cells were spotted onto synthetic complete plates lacking uracil and containing either $2 \%$ galactose or $2 \%$ glucose, respectively. For strains carrying the plasmid pRS316- $\mathrm{P}_{\text {MET3- }} \boldsymbol{\gamma}$-toxin, 10 -fold serial dilutions of cells were spotted onto YEPD plates or synthetic complete plates lacking uracil and containing $0.05 \mathrm{mM}$ methionine, respectively.

\section{Plasmid constructions}

DNA manipulations, plasmid preparations, and bacterial transformations were performed according to standard protocols. To construct the plasmid pRS306-SSD1-v1 (pABY1617), a DNA fragment containing the SSD1- $v 1$ allele from plasmid YCp50SSD1-v1 (Luke et al. 1996) was released by PvuII digestion and moved into the corresponding site in plasmid pRS306. The DNA fragment containing the MET3 promoter was PCR-amplified from chromosomal DNA using oligonucleotides 5'-ACGTGA ATTCCGTTTAATTTAGTACTAACAGAG-3' (EcoRI site under- lined) and 5'-ACGTGGATCCGTTAATTATACTTTATTCTTGTT ATT-3' (BamHI site underlined). The PCR product was cut with EcoRI/BamHI and used to replaced the $\mathrm{P}_{G A L 1}$ in the plasmid pRS316-P $\mathrm{PALI}^{-} \boldsymbol{\gamma}$-toxin (pABY1472) (Lu et al. 2005), generating pRS316- $\mathrm{P}_{M E T 3}-\boldsymbol{\gamma}$-toxin (pABY1728).

\section{HPLC analysis of tRNA}

Total tRNA and single tRNA species prepared as previously described (Björk et al. 2001) were digested to nucleosides and analyzed by HPLC. The levels of modified nucleosides $\mathrm{mcm}^{5} \mathrm{U} /$ $\mathrm{mcm}^{5} \mathrm{~s}^{2} \mathrm{U}$ and $\mathrm{ncm}^{5} \mathrm{U}$ were examined using the Develosil C30 and C18 reverse-phase columns, respectively (Gehrke et al. 1982; Gehrke and Kuo 1990). Identifications of modified nucleosides $\mathrm{mcm}^{5} \mathrm{~s}^{2} \mathrm{U}, \mathrm{mcm}^{5} \mathrm{U}, \mathrm{ncm}{ }^{5} \mathrm{U}$, and $\mathrm{s}^{2} \mathrm{U}$ have previously been described (Huang et al. 2005).

\section{In vivo and in vitro cleavage of tRNA by $\gamma$-toxin}

Overnight cultures of strains to be tested were diluted in prewarmed YEPD, grown for three generations to $\mathrm{OD}_{600} \sim 0.1$, and split into two. To one-half, crude zymocin (Butler et al. 1991b) was added to a concentration of $7 \%(\mathrm{vol} / \mathrm{vol})$; the other untreated half served as a control. The cells were harvested $3 \mathrm{~h}$ after treatment, and total RNA was prepared using hot phenol (Ausubel et al. 2001). For the in vitro cleavage assay, total tRNA was isolated from exponentially growing cultures and treated with purified $\gamma$ toxin-GST or GST at a concentration of $5 \mathrm{nM}$ as described earlier (Lu et al. 2005).

Samples of $\sim 5 \mu \mathrm{g}$ of total RNA were separated on $8 \%$ polyacrylamide, $8 \mathrm{M}$ urea gels and transferred to Zeta-Probe membranes (Bio-Rad). The oligonucleotides used to detect tRNAs were 5'-GCCCAAGAGATTTCGAGTCTCT-3' (tRNA ${ }_{\text {CGA }}^{\text {Ser }}$ ) and 5'-CTCCGCTACGGGGAGTCGAAC-3' (tRNA mcm $^{\prime} \mathrm{s}^{2} \mathrm{UUC}$, $3^{\prime}$ probe). Oligonucleotides were labeled using adenosine $\left[\gamma-{ }^{32} \mathrm{P}\right]$ triphosphate $(5000 \mathrm{Ci} / \mathrm{mmol}$; Amersham Biosciences $)$ and polynucleotide kinase (Roche Applied Science). Northern blots were visualized and quantified by PhosphorImager analysis.

\section{ACKNOWLEDGMENTS}

We thank Drs. K.T. Arndt, M.J. Stark, S.Y. Roth, and N. Gunge for strains and plasmids. We acknowledge Drs. M.J.O. Johansson, G.R. Björk, and T.G. Hagervall for critical reading of the manuscript. This work was financially supported by grants from the Swedish Cancer Foundation (07 0637), Swedish Research Council (621-2006-4269), and Bernhard and Signe Bäckström Foundation (223-438-07).

Received May 16, 2008; accepted June 27, 2008.

\section{REFERENCES}

Angeles de la Torre-Ruiz, M., Torres, J., Arino, J., and Herrero, E. 2002. Sit4 is required for proper modulation of the biological functions mediated by $\mathrm{Pkcl}$ and the cell integrity pathway in Saccharomyces cerevisiae. J. Biol. Chem. 277: 3346833476.

Ausubel, F.M., Brent, R., Kingston, R.E., Moore, D.D., Seidman, J.G., Smith, J.A., and Struhl, K 2001. Current protocols in molecular biology. John Wiley and Sons, New York. 
Björk, G.R., Jacobsson, K., Nilsson, K., Johansson, M.J., Byström, A.S., and Persson, O.P. 2001. A primordial tRNA modification required for the evolution of life? EMBO J. 20: 231-239.

Björk, G.R., Huang, B., Persson, O.P., and Byström, A.S. 2007. A conserved modified wobble nucleoside $\left(\mathrm{mcm}^{5} \mathrm{~s}^{2} \mathrm{U}\right)$ in lysyl-tRNA is required for viability in yeast. $R N A$ 13: $1245-1255$.

Burke, D., Dawson, D., and Stearns, T 2000. Methods in yeast genetics. Cold Spring Harbor Laboratory Press, New York.

Butler, A.R., Porter, M., and Stark, M.J. 1991a. Intracellular expression of Kluyveromyces lactis toxin $\gamma$ subunit mimics treatment with exogenous toxin and distinguishes two classes of toxin-resistant mutant. Yeast 7: 617-625.

Butler, A.R., White, J.H., and Stark, M.J. 1991b. Analysis of the response of Saccharomyces cerevisiae cells to Kluyveromyces lactis toxin. J. Gen. Microbiol. 137: 1749-1757.

Butler, A.R., White, J.H., Folawiyo, Y., Edlin, A., Gardiner, D., and Stark, M.J. 1994. Two Saccharomyces cerevisiae genes which control sensitivity to $\mathrm{G}_{1}$ arrest induced by Kluyveromyces lactis toxin. Mol. Cell. Biol. 14: 6306-6316.

Collier, R.J. 2001. Understanding the mode of action of diphtheria toxin: A perspective on progress during the 20th century. Toxicon 39: $1793-1803$.

DeMaggio, A.J., Lindberg, R.A., Hunter, T., and Hoekstra, M.F. 1992. The budding yeast HRR25 gene product is a casein kinase I isoform. Proc. Natl. Acad. Sci. 89: 7008-7012.

Di Como, C.J. and Arndt, K.T. 1996. Nutrients, via the Tor proteins, stimulate the association of Tap42 with type 2A phosphatases. Genes \& Dev. 10: 1904-1916.

Fichtner, L. and Schaffrath, R. 2002. KTI11 and KTI13, Saccharomyces cerevisiae genes controlling sensitivity to $G_{1}$ arrest induced by Kluyveromyces lactis zymocin. Mol. Microbiol. 44: 865-875

Fichtner, L., Frohloff, F., Burkner, K., Larsen, M., Breunig, K.D., and Schaffrath, R. 2002a. Molecular analysis of KTI12/ TOT4, a Saccharomyces cerevisiae gene required for Kluyveromyces lactis zymocin action. Mol. Microbiol. 43: 783-791.

Fichtner, L., Frohloff, F., Jablonowski, D., Stark, M.J., and Schaffrath, R. 2002b. Protein interactions within Saccharomyces cerevisiae Elongator, a complex essential for Kluyveromyces lactis zymocicity. Mol. Microbiol. 45: 817-826.

Fichtner, L., Jablonowski, D., Schierhorn, A., Kitamoto, H.K., Stark, M.J., and Schaffrath, R. 2003. Elongator's toxin-target (TOT) function is nuclear localization sequence dependent and suppressed by post-translational modification. Mol. Microbiol. 49: 1297-1307.

Fiorentini, P., Huang, K.N., Tishkoff, D.X., Kolodner, R.D., and Symington, L.S. 1997. Exonuclease I of Saccharomyces cerevisiae functions in mitotic recombination in vivo and in vitro. Mol. Cell. Biol. 17: 2764-2773.

Frohloff, F., Fichtner, L., Jablonowski, D., Breunig, K.D., and Schaffrath, R. 2001. Saccharomyces cerevisiae Elongator mutations confer resistance to the Kluyveromyces lactis zymocin. EMBO J. 20: 1993-2003.

Frohloff, F., Jablonowski, D., Fichtner, L., and Schaffrath, R. 2003. Subunit communications crucial for the functional integrity of the yeast RNA polymerase II elongator [ $\gamma$-toxin target (TOT)] complex. J. Biol. Chem. 278: 956-961.

Furukawa, K., Mizushima, N., Noda, T., and Ohsumi, Y. 2000. A protein conjugation system in yeast with homology to biosynthetic enzyme reaction of prokaryotes. J. Biol. Chem. 275: 74627465 .

Gavin, A.C., Aloy, P., Grandi, P., Krause, R., Boesche, M., Marzioch, M., Rau, C., Jensen, L.J., Bastuck, S., Dumpelfeld, B., et al. 2006. Proteome survey reveals modularity of the yeast cell machinery. Nature 440: 631-636.

Gehrke, C.W. and Kuo, K.C.T 1990. Chromatography and modification of nucleosides.. Elsevier, Amsterdam, New York.

Gehrke, C.W., Kuo, K.C., McCune, R.A., Gerhardt, K.O., and Agris, P.F. 1982. Quantitative enzymatic hydrolysis of tRNAs:
Reversed-phase high-performance liquid chromatography of tRNA nucleosides. J. Chromatogr. 230: 297-308.

Gerber, J., Neumann, K., Prohl, C., Muhlenhoff, U., and Lill, R. 2004. The yeast scaffold proteins Isulp and Isu2p are required inside mitochondria for maturation of cytosolic Fe/S proteins. Mol. Cell. Biol. 24: 4848-4857.

Goehring, A.S., Rivers, D.M., and Sprague Jr., G.F. 2003. Attachment of the ubiquitin-related protein Urm1p to the antioxidant protein Ahp1p. Eukaryot. Cell 2: 930-936.

Gunge, N. and Sakaguchi, K. 1981. Intergeneric transfer of deoxyribonucleic acid killer plasmids, pGK11 and pGK12, from Kluyveromyces lactis into Saccharomyces cerevisiae by cell fusion.J. Bacteriol. 147: 155-160.

Ho, Y., Mason, S., Kobayashi, R., Hoekstra, M., and Andrews, B. 1997. Role of the casein kinase I isoform, Hrr25, and the cell cycleregulatory transcription factor, $\mathrm{SBF}$, in the transcriptional response to DNA damage in Saccharomyces cerevisiae. Proc. Natl. Acad. Sci. 94: 581-586.

Ho, Y., Gruhler, A., Heilbut, A., Bader, G.D., Moore, L., Adams, S.L., Millar, A., Taylor, P., Bennett, K., Boutilier, K., et al. 2002. Systematic identification of protein complexes in Saccharomyces cerevisiae by mass spectrometry. Nature 415: 180-183.

Hochstrasser, M. 2000. Evolution and function of ubiquitin-like protein-conjugation systems. Nat. Cell Biol. 2: E153-E157.

Hoekstra, M.F., Liskay, R.M., Ou, A.C., DeMaggio, A.J., Burbee, D.G., and Heffron, F. 1991. HRR25, a putative protein kinase from budding yeast: association with repair of damaged DNA. Science 253: 1031-1034.

Huang, B., Johansson, M.J., and Byström, A.S. 2005. An early step in wobble uridine tRNA modification requires the Elongator complex. RNA 11: 424-436.

Jablonowski, D. and Schaffrath, R. 2007. Zymocin, a composite chitinase and tRNase killer toxin from yeast. Biochem. Soc. Trans. 35: 1533-1537.

Jablonowski, D., Butler, A.R., Fichtner, L., Gardiner, D., Schaffrath, R., and Stark, M.J. 2001a. Sit4p protein phosphatase is required for sensitivity of Saccharomyces cerevisiae to Kluyveromyces lactis zymocin. Genetics 159: 1479-1489.

Jablonowski, D., Frohloff, F., Fichtner, L., Stark, M.J., and Schaffrath, R. 2001b. Kluyveromyces lactis zymocin mode of action is linked to RNA polymerase II function via Elongator. Mol. Microbiol. 42: 1095-1105.

Jablonowski, D., Fichtner, L., Stark, M.J., and Schaffrath, R. 2004. The yeast Elongator histone acetylase requires Sit4-dependent dephosphorylation for toxin-target capacity. Mol. Biol. Cell 15: 14591469.

Jablonowski, D., Zink, S., Mehlgarten, C., Daum, G., and Schaffrath, R. 2006. tRNA wobble uridine methylation by Trm9 identifies Elongator's key role for zymocin-induced cell death in yeast. Mol. Microbiol. 59: 677-688.

Jiang, Y. 2006. Regulation of the cell cycle by protein phosphatase $2 \mathrm{~A}$ in Saccharomyces cerevisiae. Microbiol. Mol. Biol. Rev. 70: 440-449.

Johansson, M.J., Esberg, A., Huang, B., Björk, G.R., and Byström, A.S. 2008. Eukaryotic wobble uridine modifications promote a functionally redundant decoding system. Mol. Cell. Biol. 28: 33013312.

Kafadar, K.A., Zhu, H., Snyder, M., and Cyert, M.S. 2003. Negative regulation of calcineurin signaling by Hrr25p, a yeast homolog of casein kinase I. Genes \& Dev. 17: 2698-2708.

Kalhor, H.R. and Clarke, S. 2003. Novel methyltransferase for modified uridine residues at the wobble position of tRNA. Mol. Cell. Biol. 23: 9283-9292.

Kawamoto, S., Sasaki, T., Itahashi, S., Hatsuyama, Y., and Ohno, T. 1993. A mutant allele skt5 affecting protoplast regeneration and killer toxin resistance has double mutations in its wild-type structural gene in Saccharomyces cerevisiae. Biosci. Biotechnol. Biochem. 57: 1391-1393.

Kishida, M., Tokunaga, M., Katayose, Y., Yajima, H., KawamuraWatabe, A., and Hishinuma, F. 1996. Isolation and genetic 
characterization of pGKL killer-insensitive mutants ( $i k i)$ from Saccharomyces cerevisiae. Biosci. Biotechnol. Biochem. 60: 798-801.

Krogan, N.J. and Greenblatt, J.F. 2001. Characterization of a sixsubunit holo-elongator complex required for the regulated expression of a group of genes in Saccharomyces cerevisiae. Mol. Cell. Biol. 21: 8203-8212.

Krogan, N.J., Cagney, G., Yu, H., Zhong, G., Guo, X., Ignatchenko, A., Li, J., Pu, S., Datta, N., Tikuisis, A.P., et al. 2006. Global landscape of protein complexes in the yeast Saccharomyces cerevisiae. Nature 440: 637-643.

Liu, S. and Leppla, S.H. 2003. Retroviral insertional mutagenesis identifies a small protein required for synthesis of diphthamide, the target of bacterial ADP-ribosylating toxins. Mol. Cell 12: 603-613.

Longtine, M.S., McKenzie III., A., Demarini, D.J., Shah, N.G., Wach, A., Brachat, A., Philippsen, P., and Pringle, J.R. 1998. Additional modules for versatile and economical PCR-based gene deletion and modification in Saccharomyces cerevisiae. Yeast 14: 953-961.

Lu, J. 2007. The Kluyveromyces lactis killer toxin is a transfer RNA endonuclease. Ph.D. thesis, Umeå University, Umeå, Sweden.

Lu, J., Huang, B., Esberg, A., Johansson, M.J., and Byström, A.S. 2005. The Kluyveromyces lactis $\gamma$-toxin targets tRNA anticodons. RNA 11: $1648-1654$.

Lu, J., Esberg, A., Huang, B., and Byström, A.S. 2008. Kluyveromyces lactis $\gamma$-toxin, a ribonuclease that recognizes the anticodon stem loop of tRNA. Nucleic Acids Res. 36: 1072-1080.

Luke, M.M., Della Seta, F., Di Como, C.J., Sugimoto, H., Kobayashi, R., and Arndt, K.T. 1996. The SAP, a new family of proteins, associate and function positively with the SIT4 phosphatase. Mol. Cell. Biol. 16: 2744-2755.

Mao, X., Hu, Y., Liang, C., and Lu, C. 2002. MET3 promoter: A tightly regulated promoter and its application in construction of conditional lethal strain. Curr. Microbiol. 45: 37-40.

Mehlgarten, C. and Schaffrath, R. 2003. Mutant casein kinase I (Hrr25p/Kti14p) abrogates the $\mathrm{G}_{1}$ cell cycle arrest induced by Kluyveromyces lactis zymocin in budding yeast. Mol. Genet. Genomics 269: 188-196.

Murakami, A., Kimura, K., and Nakano, A. 1999. The inactive form of a yeast casein kinase I suppresses the secretory defect of the $\sec 12$ mutant. Implication of negative regulation by the Hrr25 kinase in the vesicle budding from the endoplasmic reticulum. J. Biol. Chem. 274: 3804-3810.

Nakai, Y., Nakai, M., Hayashi, H., and Kagamiyama, H. 2001. Nuclear localization of yeast $\mathrm{Nfs} 1 \mathrm{p}$ is required for cell survival. J. Biol. Chem. 276: 8314-8320.

Nakai, Y., Umeda, N., Suzuki, T., Nakai, M., Hayashi, H., Watanabe, K., and Kagamiyama, H. 2004. Yeast Nfs1p is involved in thio-modification of both mitochondrial and cytoplasmic tRNAs. J. Biol. Chem. 279: 12363-12368.

Nakai, Y., Nakai, M., Lill, R., Suzuki, T., and Hayashi, H. 2007. Thio modification of yeast cytosolic tRNA is an iron-sulfur proteindependent pathway. Mol. Cell. Biol. 27: 2841-2847.
Otero, G., Fellows, J., Li, Y., de Bizemont, T., Dirac, A.M., Gustafsson, C.M., Erdjument-Bromage, H., Tempst, P., and Svejstrup, J.Q. 1999. Elongator, a multisubunit component of a novel RNA polymerase II holoenzyme for transcriptional elongation. Mol. Cell 3: 109-118.

Petrakis, T.G., Sogaard, T.M., Erdjument-Bromage, H., Tempst, P., and Svejstrup, J.Q. 2005. Physical and functional interaction between Elongator and the chromatin-associated Ktil2 protein. J. Biol. Chem. 280: 19454-19460.

Petronczki, M., Matos, J., Mori, S., Gregan, J., Bogdanova, A., Schwickart, M., Mechtler, K., Shirahige, K., Zachariae, W., and Nasmyth, K. 2006. Monopolar attachment of sister kinetochores at meiosis I requires casein kinase 1. Cell 126: 10491064.

Schafer, T., Strauss, D., Petfalski, E., Tollervey, D., and Hurt, E. 2003. The path from nucleolar $90 \mathrm{~S}$ to cytoplasmic $40 \mathrm{~S}$ pre-ribosomes. EMBO J. 22: 1370-1380.

Schafer, T., Maco, B., Petfalski, E., Tollervey, D., Bottcher, B., Aebi, U., and Hurt, E. 2006. Hrr25-dependent phosphorylation state regulates organization of the pre-40S subunit. Nature 441: 651-655.

Schaffrath, R. and Meinhardt, F. 2005. Kluyveromyces lactis zymocin and other plasmid-encoded yeast killer toxins. In Microbial protein toxins. Topics in current genetics 11 (ed. M. Schmitt), pp. 133-155. Springer, New York.

Schnell, J.D. and Hicke, L. 2003. Nontraditional functions of ubiquitin and ubiquitin-binding proteins. J. Biol. Chem. 278: 35857-35860.

Stark, M.J., Boyd, A., Mileham, A.J., and Romanos, M.A. 1990. The plasmid-encoded killer system of Kluyveromyces lactis. A review. Yeast 6: 1-29.

Sun, J., Zhang, J., Wu, F., Xu, C., Li, S., Zhao, W., Wu, Z., Wu, J., Zhou, C.Z., and Shi, Y. 2005. Solution structure of Ktillp from Saccharomyces cerevisiae reveals a novel zinc-binding module. Biochemistry 44: 8801-8809.

Sutton, A., Immanuel, D., and Arndt, K.T. 1991. The SIT4 protein phosphatase functions in late $\mathrm{G}_{1}$ for progression into $\mathrm{S}$ phase. Mol. Cell. Biol. 11: 2133-2148.

Winkler, G.S., Petrakis, T.G., Ethelberg, S., Tokunaga, M., ErdjumentBromage, H., Tempst, P., and Svejstrup, J.Q. 2001. RNA polymerase II elongator holoenzyme is composed of two discrete subcomplexes. J. Biol. Chem. 276: 32743-32749.

Wittschieben, B.O., Otero, G., de Bizemont, T., Fellows, J., ErdjumentBromage, H., Ohba, R., Li, Y., Allis, C.D., Tempst, P., and Svejstrup, J.Q. 1999. A novel histone acetyltransferase is an integral subunit of elongating RNA polymerase II holoenzyme. Mol. Cell 4: $123-128$.

Zheng, L., Cash, V.L., Flint, D.H., and Dean, D.R. 1998. Assembly of iron-sulfur clusters. Identification of an iscSUA-hscBA-fdx gene cluster from Azotobacter vinelandii. J. Biol. Chem. 273: 1326413272. 

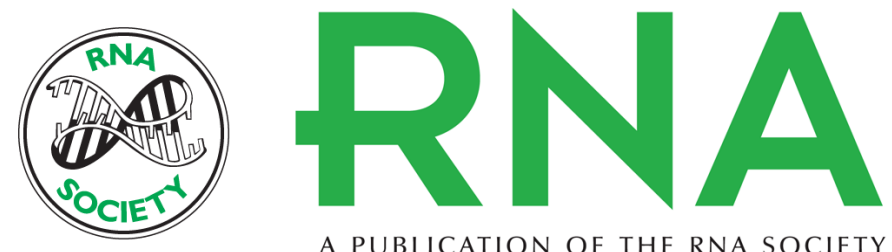

A PUBLICATION OF THE RNA SOCIETY

\section{A genome-wide screen identifies genes required for formation of the wobble nucleoside 5-methoxycarbonylmethyl-2-thiouridine in Saccharomyces cerevisiae}

Bo Huang, Jian Lu and Anders S. Byström

RNA 2008 14: 2183-2194 originally published online August 28, 2008

Access the most recent version at doi:10.1261/rna.1184108

References This article cites 63 articles, 35 of which can be accessed free at:

http://rnajournal.cshlp.org/content/14/10/2183.full.html\#ref-list-1

License

Email Alerting Receive free email alerts when new articles cite this article - sign up in the box at the Service top right corner of the article or click here.

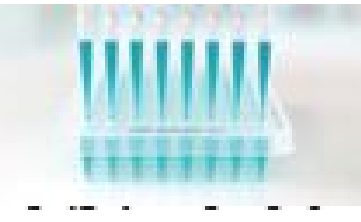

Providing Precise Solutions for your research.

To subscribe to RNA go to:

http://rnajournal.cshlp.org/subscriptions 